\title{
SLC27A4 Gene
}

National Cancer Institute

\section{Source}

National Cancer Institute. SLC27A4 Gene. NCI Thesaurus. Code C106334.

This gene is involved in both fatty acid transport and metabolism. 